\title{
Path analysis on traits associated with oat milling yield
}

\author{
Cezar Verdi ${ }^{1}$, Vianei Rother ${ }^{1}$, Ivan Ricardo Carvalho ${ }^{1}$, Liamara Bahr Thurow ${ }^{1}$, Rafael Nornberg ${ }^{2}$, Victoria \\ Freitas de Oliveira ${ }^{1}$, Luciano Carlos da Maia ${ }^{1}$ and Antonio Costa de Oliveira ${ }^{1}$
}

${ }^{1}$ Universidade Federal de Pelotas, Pelotas, RS, BraZil. ${ }^{2}$ OR Melhoramento de Sementes Ltda., Passo Fundo, RS, Brazil.

*Author for correspondence: antonio.oliveira@pq.cnpq.br

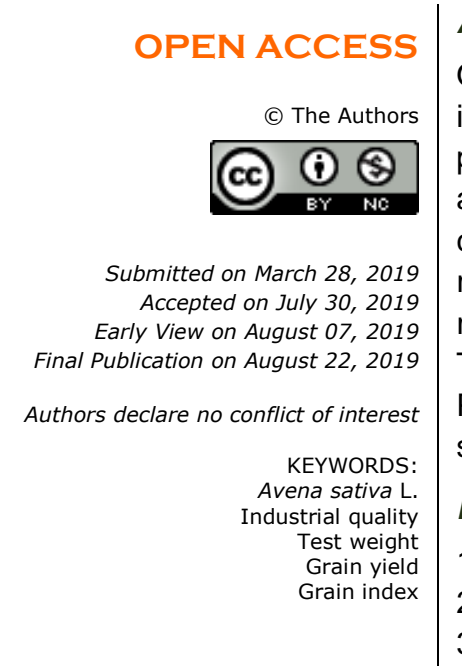

\section{ABSTRACT}

Oat is an important winter cereal used for food and feed. The industrial crop yield is an important parameter to characterize the quality of the grain and the conversion of this in processed products. Thus, this study aimed to identify the phenotypic inter-relations of cause and effect between traits associated with the industrial yield of oat. The experiment was conducted in the growing seasons of 2013 and 2014. The experimental design was a randomized block, arranged in a factorial design: two (harvests) x 20 (genotypes), with six replicates. The oat genotypes formed different phenotypic classes for the measured traits. The industrial yield is directly associated with the test weight, grain yield and grain index. Phenotypic associations can be efficiently used in breeding programs aiming at oat indirect selection to improve industrial performance.

\section{Highlighted Conclusions}

1. Different phenotypic classes are observed for the measured traits.

2. Milling yield is associated with the hectoliter weight, grain yield and grain index.

3. The milling yield can be improved by indirect selection.

\section{INTRODUCTION}

The oat (Avena sativa L.) crop is a grass species that has increased its yields and acreage in Southern and Midwest Brazil. Multiple possibilities of use are noted for this crop, as the grain production, forage, soil cover and crop rotation (Federizzi et al. 2014). Use of this cereal in processed food has been increasing, since it represents a valuable source at the nutritional level, due to the quality of its protein, lipid ratio and dietary fiber (Jamil et al. 2016).

The demand for increase in production and the crop advances in new regions require not only a high yielding but also high-quality oats, with well-formed, high mass and large grains. These traits when combined increment the revenue of farmers and industry, benefitting both (Alves and Kist 2010).

Due to the large number of traits to be reconciled in a superior genotype, effective strategies that allow one to understand which traits are associated with industrial yield of oat are needed. Thus, the trends knowledge and phenotypic relationships between traits can be revealed through the linear correlation, but its direct interpretation may result in some errors. The interpretation of the magnitude and direction of a correlation can result in mistakes in selection strategy addressed by the breeder, because this association may be due to the action of a third trait or group of traits (Cruz et al. 2012).

In order to better employ the trait interrelations in breeding oat, techniques can be employed for the deployment of linear associations in cause and effect relationships through pathway analysis (Wright 1921), which allows to determinate the direct and indirect effects of explanatory traits in dependent trait (Cruz et al. 2014). There is a lack of information relating to which traits are associated phenotypically with oat industrial yield, and helps the breeder choosing the best indirect selection strategy. This work aimed to identify the phenotypic interrelations of cause and effect between traits associated with the oat industrial yield.

\section{MATERIAL AND METHODS}

The experiment was conducted in the growing seasons of 2013 and 2014 in the experimental area of the Plant Genomics and Breeding Center, belonging to the Federal University of Pelotas. The experimental area is located in 
Capão do Leão county, state of Rio Grande do Sul - RS, in coordinates: latitude $31^{\circ} 47^{\prime} 58^{\prime} S$ and longitude $52^{\circ} 31^{\prime}$ 02 'WGr., and altitude of 13.2 meters. The climate, according to Köppen, is classified as Cfa, with an average annual rainfall of $1280 \mathrm{~mm}$. The soil is characterized as Argisol red yellow dystrophic.

The design used was randomized blocks, organized in fatorial scheme, beeing two (growing seasons) x 20 (oat genotypes), established in six replicates. The genotypes used were: URS Gaudéria, UPFA Ouro, UPFPS Farroupilha, IPR Afrodite, URS FAPA Slava, Barbarasul, Brisasul, FAEM 4 Carlasul, FAEM 5 Chiarasul, FAEM 006, URS 21, URS Guapa, URS Taura, URS Tarimba, URS Guria, URS Charrua, URS Torena, URS Corona, URS Estampa and URS Guará.

The experimental unit was constituted per five rows of five meters $(\mathrm{m})$ long, spaced per $0.17 \mathrm{~m}$. The useful area was composed by tree central rows and totalizing $2.5 \mathrm{~m}^{2}$. The direct seeding system was adopted, with basic fertilization as $400 \mathrm{~kg} \mathrm{ha}^{-1}$ of NPK basic fertilization in the 05-20-20 formulation, and a topdressing was performed with $150 \mathrm{~kg} \mathrm{ha}^{-1}$ of nitrogen, in the urea form $\left((\mathrm{NH} 2)_{2} \mathrm{CO}\right)$ at tillering stage $(21)$ by Zadoks scale, adapted by Luche et al. (2014). The population density used for all genotypes was of 300 viable plants per $\mathrm{m}^{2}$. The weed, insectspests and disease control was performed in such a way to minimize interference from biotic stresses on the experiment.

The target traits were obtained by measuring all plants contained in the area of each experimental unit, these being: days to flowering (DF) in days, reproductive period (RP) in days, cycle duration (CD) in days, lodging percentage (LP), thousand grain weight (TGW) in grams, hectoliter weight (HW) in $\mathrm{kg} \mathrm{hL}^{-1}$, grain yield (GY) in $\mathrm{kg}$ $\mathrm{ha}^{-1}$, grain index $(\mathrm{Gl})$ in $\mathrm{g} \mathrm{g}^{-1}$, husking index $(\mathrm{HI})$ in $\mathrm{g} \mathrm{g}^{-1}$ and milling yield $(\mathrm{MY})$ in $\mathrm{kg} \mathrm{ha}^{-1}$.

The data were submitted to an analysis of variance together with an $F$ test $(p \leq 0.05)$, where the assumptions were checked, and conducted descriptive analysis through the distribution of frequencies of phenotypic classes for each trait. Later, the traits where submitted to a joint Pearson linear correlation analysis covering the two seasons, in order to reveal the trend between traits. The phenotypic matrix was submitted to a multicollinearity diagnosis, through the number of matrix conditions (NMC), and a path analysis was performed with adjustment of the $k$ value, where it set the milling yield (MY) as a dependent trait, and the others traits as explanatory (Cruz et al. 2012). The statistical analysis was performed using the statistical software Genes (Cruz 2013).

\section{RESULTS AND DISCUSSION}

The analysis of variance revealed significant interaction $(p \leq 0.05)$ between season $x$ oat genotypes for the traits days to flowering (DF), reproductive period (RP), cycle duration (CD), Thousand grain weight (TGW), hectoliter weight (HW), grain yield (GY) and milling yield (MY). In contrast, no significant interaction was identified for lodging percentage (LP), grain index (GI) and grain yield (GY). In order to better represent the distribution of phenotypic frequencies, the trends and interrelations between traits, it was jointly considered the results obtained in the season, for the best representation of the traits measured in oat.

The trait days to flowering (DF) formed five phenotypic classes with amplitude of 71 to 78 days (Figure $1 \mathrm{~A}$ ). The classes with 72,74 and 75 days they made up $90 \%$ of the genotypes studied. A study conducted with 15 oat genotypes revealed that the average for flowering date was 85 days, when these genotypes are characterized as early, thus, reducing the cycle resulted in an earlier harvest of grain (Barbosa Neto et al. 2000). Shorter periods of development may be due to the time of sowing employed, and the occurrence of high temperatures (Castro et al. 2012).

The reproductive period (RP) afforded the formation of five phenotypic classes, with an amplitude from 28 to 32 days (Figure 1B). The phenotypic classes of 31 and 32 days correspond to $60 \%$ of the genotypes. For this cereal, longer reproductive cycles are desirable because they allow plants to target the maximum of assimilates to the grains, leading to higher grain mass and dimensions, becoming qualitatively superior (Hartwig et al. 2007).

The trait cycle duration (CD) displays a low amplitude ranging from 103 to 107 days (Figure 1C), showing that, for both environments, the genotypes remained very close. This trait is highly influenced by the environment, especially through the occurrence of high temperatures during the cycle (Castro et al. 2012). This genotypeenvironment interaction, especially with respect to temperature and photoperiod, directly affects the phyllochron and the phenological development of the crop (Duarte et al. 2017).

The analysis of lodging percentage (LP) allowed the formation of five phenotypic classes ranging from 27 to $57 \%$ (Figure 1D). Of these, $75 \%$ of genotypes displayed between 39 and $45 \%$ of lodging. This trait is influenced by factors related to genotype as well as cultivation environment (Hawerroth et al. 2015). Plant height was characterized as a crucial factor for the proportion of lodged plants in the field (Oliveira et al. 2011). The high lodging percentage promotes losses in yield, grain quality, fewer number of panicles and grains per unit area, as well as degradation of grain nutritional components (Hartwig et al. 2007). 

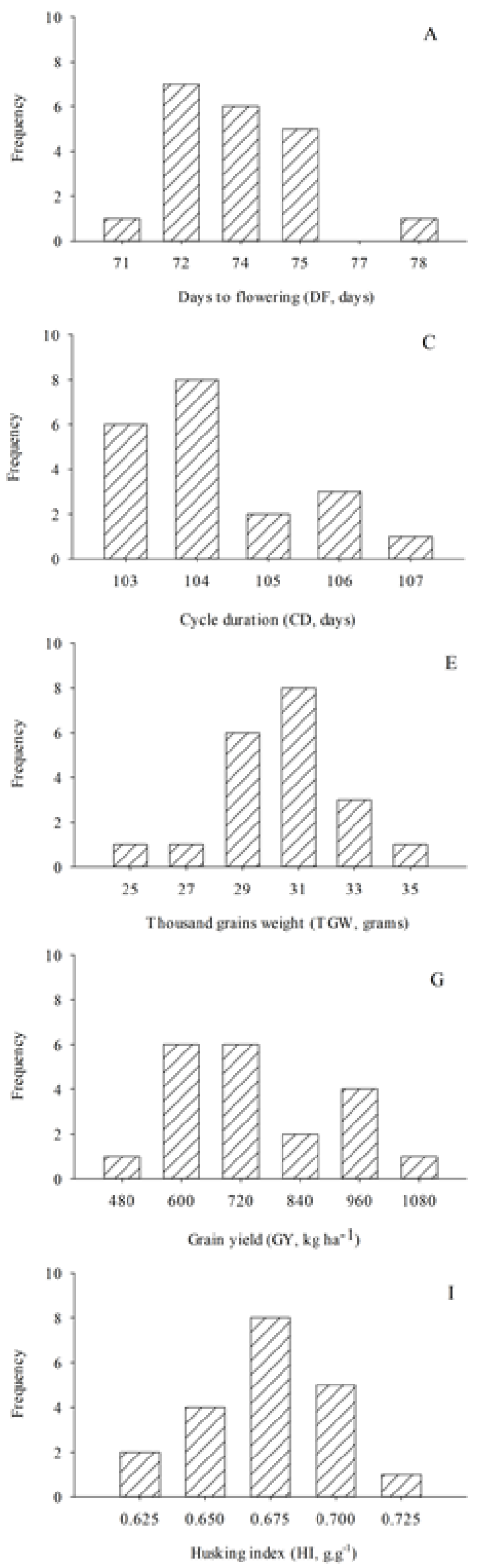
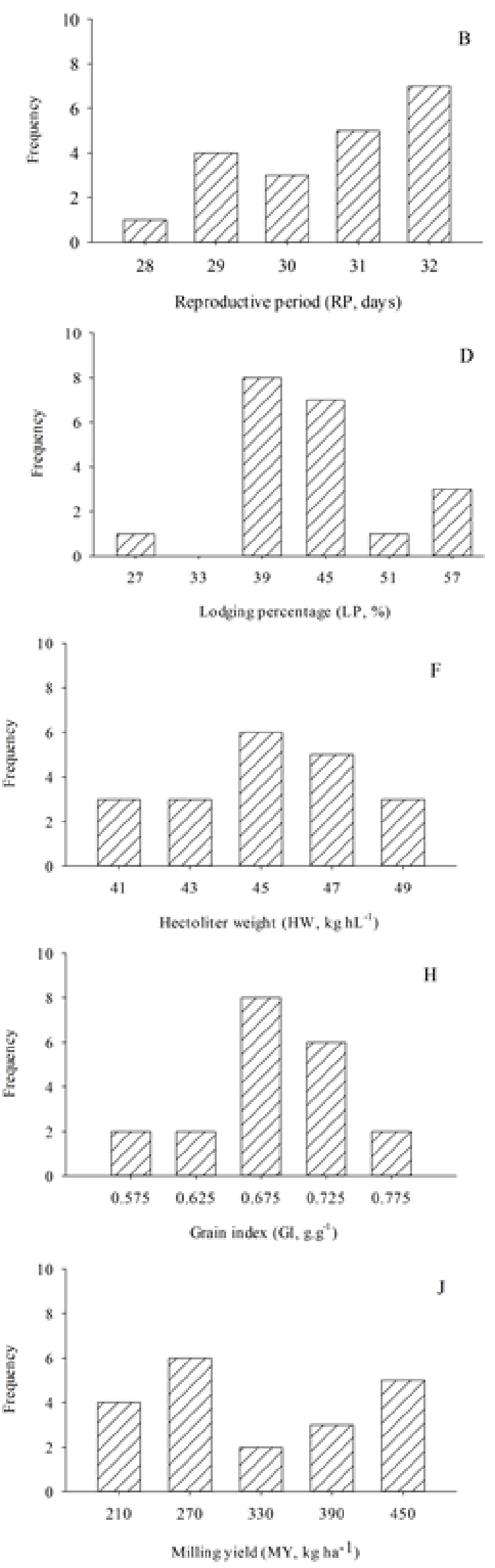

Figure 1. Graphics of frequency distribution of phenotypic classes to, (A) days to flowering (DF); (B) reproductive period (RP); (C) cycle duration (CD); (D) lodging percentage (LP); (E) thousand grain weight (TGW); (F) hectoliter weight (HW); (G) grain yield (GY); (H) grain index (GI); (I) husking index (HI); (J) milling index (MI), earned in agricultural crop of 2013 and 2014. 
The analysis of thousand grain weight (TGW) allowed the formation of six phenotypic classes with amplitude ranging from 25 to $35 \mathrm{~g}$ (Figure $1 \mathrm{E}$ ), where the classes with 29 and $31 \mathrm{~g}$ comprised $70 \%$ of the genotypes. This trait is quite variable in oats, because it is dependent on the number of grains per panicle, where inverse associations have been observed between number and effective grain size (lannucci et al. 2011).

The hectoliter weight (HW) showed the formation of five phenotypic classes with amplitude ranging from 41 to $49 \mathrm{~kg} \mathrm{hL}^{-1}$ (Figure 1F), with classes 45 and $47 \mathrm{~kg} \mathrm{hL}^{-1}$ containing $55 \%$ of the genotypes. This trait can be regarded as an indirect indicator of the quality of grain produced and predetermine the yield in the industrial processing of these grains (Lângaro et al. 2014). Reproductive period is essential for good HW performance, therefore breeding programs have sought to make it longer compared to the vegetative period (Dumlupinar et al. 2012).

Grain yield (GY) formed six phenotypic classes with an amplitude ranging from 480 to $1,080 \mathrm{~kg} \mathrm{ha}^{-1}$ (Figure 1G). These GY magnitudes resulted from the fact that most genotypes were developed in contrasting environments with better growing conditions than the environment being studied (Lorencetti et al. 2005). The classes between 600 and $720 \mathrm{~kg} \mathrm{ha}^{-1}$ comprised $60 \%$ of the genotypes, due to more stringent growing conditions, high disease pressure, excessive rainfall and high temperatures in the growing season. Research conducted in Pelotas-RS per three years of cultivation and five oat genotypes revealed general average for grain yield ranging from 839 to $1,450 \mathrm{~kg} \mathrm{ha}^{-1}$ (Nornberg et al. 2014).

The grain index (Gl) trait allowed the formation of five phenotypic classes and amplitude ranging from 0.57 to 0.77 (Figure $1 \mathrm{H})$, being the classes 0.67 and 0.72 responsible per $70 \%$ of the genotypes. This trait is related to the amount of grain that will be effectively processed by the industry, where larger grains with higher and uniform mass have the desired pattern. However, it is characterized as a problem for the breeding in obtaining genotypes with more reconciled grains the greater mass (Caierão et al. 2001).

The analysis of the husking index $(\mathrm{HI})$ indicated five phenotypic classes ranging from 0.62 to 0.72 (Figure 1I), and the class 0.67 responsible per $40 \%$ of the genotypes. This index is very important because it represents the effective ratio of the caryopsis with full conditions to be processed. The industry seeks genotypes with higher grain and increased kernel/hull ratio (Hawerroth et al. 2014).

The milling yield (MY) analysis indicated the presence of five phenotypic classes, with amplitude ranging from 210 to $450 \mathrm{~kg} \mathrm{ha}^{-1}$ (Figure 1J), a phenotypic class with $270 \mathrm{~kg} \mathrm{ha}^{-1}$ stood out with $30 \%$ of the evaluated oat genotypes. Similar values were obtained for this trait, also in the same cultivation environment, showing reduced grain yield and low levels of milling yield (Nornberg et al. 2014). Highest milling yields are obtained through genotypes with uniform grains, larger grains, and high yields (Hawerroth et al. 2014).

The study of linear correlations is very useful to breeding programs, since it allows one to identify the magnitude and trend of the associations between the measured traits (Cruz et al. 2014). The Pearson linear correlation coefficients are divided in: null $(r=0.00)$; low ( $r=0.00$ to $r=0.30)$; medium ( $r=0.30$ to $r=0.60)$; high ( $r=0.60$ to $r=1.00$ ) according to Carvalho et al. (2004). The linear associations were conducted by measuring ten agronomic traits in the crop year of 2013 and 2014 in 20 oat genotypes (Table 1), corresponding to a sample size of 240 observations.

Table 1. Pearson linear correlation estimates for important agronomical target traits of 20 oat genotypes in agricultural crop of 2013 and 2014, Pelotas - RS, 2018.

\begin{tabular}{|c|c|c|c|c|c|c|c|c|c|c|}
\hline & DF & $\mathrm{RP}$ & $C D$ & LP & TGW & HW & GY & $\mathrm{GI}$ & $\mathrm{HI}$ & MY \\
\hline $\mathrm{DF}^{(1)}$ & - & $-0.614^{*}$ & $0.622^{*}$ & $-0.433^{*}$ & $0.347^{*}$ & $0.459^{*}$ & $-0.205^{*}$ & $0.253^{*}$ & $0.216^{*}$ & -0.104 \\
\hline $\mathrm{RP}$ & & - & $0.168^{*}$ & 0.087 & -0.031 & -0.089 & 0.030 & 0.040 & $-0.149^{*}$ & 0.010 \\
\hline CD & & & - & $-0.475^{*}$ & $0.420^{*}$ & $0.492^{*}$ & $-0.231^{*}$ & $0.393^{*}$ & 0.089 & -0.102 \\
\hline LP & & & & - & $-0.454^{*}$ & $-0.646^{*}$ & $-0.214^{*}$ & $-0.256^{*}$ & $-0.239^{*}$ & $-0.271^{*}$ \\
\hline TGW & & & & & - & $0.568^{*}$ & 0.120 & $0.605^{\star}$ & $0.243^{*}$ & $0.242^{*}$ \\
\hline HW & & & & & & - & $0.426^{*}$ & $0.353^{*}$ & $0.486^{*}$ & $0.516^{*}$ \\
\hline GY & & & & & & & - & -0.033 & $0.313^{*}$ & $0.897^{*}$ \\
\hline $\mathrm{Gl}$ & & & & & & & & - & 0.106 & $0.257^{*}$ \\
\hline $\mathrm{HI}$ & & & & & & & & & - & $0.419^{*}$ \\
\hline MY & & & & & & & & & & - \\
\hline
\end{tabular}

* coefficients of Pearson linear correlation ( $n=240)$ significant $(p \leq 0.05) .{ }^{(1)}$ days to the flowering (DF); reproductive period (RP); cycle duration (CD); lodging percentage (LP); thousand grain weight (TGW); hectoliter weight (HW); grains yield (GY); grains index (GI); husking index (HI); milling yield (MY). 
The Pearson linear correlation analysis revealed 45 associations between the traits, being 33 of these significant $(p \leq 0.05)$. Thus, the thousand grain weight (TGW) revealed a positive trend of intermediate magnitude with HW ( $r=0.56)$, high positive with $\mathrm{Gl}(r=0.60)$ and low positive to $\mathrm{HI}(r=0.24)$ and MY $(r=0.24)$. Research show positive trends and low magnitude between the thousand grain weight and number of grains per plant (Caierão et al. 2001).

The milling yield (MY) showed high positive association with GY ( $r=0.89)$, intermediate and positive with HW $(r=0.51)$ and $\mathrm{HI}(r=0.41)$ and low and positive with $\mathrm{Gl}(r=0.25)$. However, low and negative trends with LP $(r=-0.27)$. The milling yield is dependent on the joint action of genotypes with higher grain yield, grain larger than two millimeters and that meet the industry standards (Lângaro et al. 2014).

The trait days to flowering (DF) revealed high positive trends with $C D(r=0.62)$, intermediate and positive with HW ( $r=0.45)$ and TGW ( $r=0.34)$, low and positive with $\mathrm{GI}(r=0.25)$ and $\mathrm{HI}(r=0.21)$. However, high and negative trends with RP ( $r=-0.61)$, intermediate and negative with LP $(r=-0.43)$, and low and negative with $G Y(r=-0.20)$. The reproductive period (RP) showed a low and positive association with $C D(r=0.16)$, but low and negative with $\mathrm{HI}(\mathrm{r}=-$ 0.14). Studies have determined that grain yield gains can be achieved by genotypes which show short vegetative period, and longer reproductive period, resulting in longer time to carry the assimilated products to the grains, and thereby obtaining larger grain size and weight (Hawerroth et al. 2014).

The cycle duration (DC) provided intermediate and positive trends with TGW ( $r=0.42)$ and HW ( $r=0.49)$, but low and positive with $\mathrm{Gl}(\mathrm{r}=0.39)$. However, intermediate and negative trends with LP ( $r=-0.47)$ and low and negative with GY $(r=-0.23)$. The oat cycle is influenced by the occurrence of high temperatures, since it leads to an increase in the growth rate which results in reducing the time between seeding and the physiological maturity (Castro et al. 2012).

The lodging percentage (LP) showed a high and negative association with HW ( $r=-0.64)$, intermediate with TGW $(\mathrm{r}=-0.45)$, and low with $\mathrm{GY}(\mathrm{r}=-0.21), \mathrm{IG}(\mathrm{r}=-0.25)$ and $\mathrm{HI}(\mathrm{r}=-0.23)$. The lodging tends to reduce the oat yield potential and grain quality, reducing the number of plants, panicles and grains per unit area. Also, the grains of lodged plants get in contact with the ground, degrading their components (Hartwig et al. 2007).

The phenotypic matrix of linear associations was subjected to a multicollinearity diagnosis for the traits DF, RP, CD, LP, TGW, HW, GY, GI, HI and MY. Thus, there was a moderate to strong multicollinearity $(100<N M C<1000)$. When the trait $\mathrm{HI}$ was removed, then a NMC value of 93.9 was obtained, suggesting a weak multicollinearity without serious problems in the matrix. In order to better demonstrate the phenotypic associations of cause and effect in the path analysis, we used the index $k 0.018$ for setting the phenotypic effects.

The phenotypic path analysis was performed using the results obtained with 20 oat genotypes (Table 2). Therefore, the milling yield (MY) trait stood as a dependent, this trait representing the amount of grains actually suitable to the industry, and reveals significant economic importance for oat (Crestani et al. 2010). The traits DF, RP, CD, LP, TGW, HW, MY and Gl were deemed explicative.

Table 2. Estimated direct and indirect phenotype effects of eight target agronomic traits on the milling yield (MY), from 20 oat genotypes in the agricultural seasons of 2013 and 2014.

\begin{tabular}{|c|c|c|c|c|c|c|c|c|}
\hline & \multicolumn{8}{|c|}{ Explanatory traits } \\
\hline & $\overline{\mathrm{DF}}$ & $\mathrm{RP}$ & CD & LP & TGW & HW & GY & GI \\
\hline Direct effect & -0.098 & -0.081 & 0.021 & 0.005 & -0.096 & 0.135 & 0.835 & 0.310 \\
\hline IND. EFFECT BY DF & - & 0.060 & -0.061 & 0.042 & -0.034 & -0.045 & 0.020 & -0.025 \\
\hline IND. EFFECT BY RP & 0.050 & - & -0.014 & -0.007 & 0.002 & 0.007 & -0.002 & -0.003 \\
\hline IND. EFFECT BY CD & 0.013 & 0.003 & - & -0.010 & 0.009 & 0.010 & -0.005 & 0.008 \\
\hline IND. EFFECT BY LP & -0.002 & 0.000 & -0.003 & - & -0.002 & -0.004 & -0.001 & -0.001 \\
\hline IND. EFFECT BY TGW & -0.033 & 0.003 & -0.040 & 0.043 & - & -0.054 & -0.011 & -0.058 \\
\hline IND. EFFECT BY HW & 0.062 & -0.012 & 0.066 & -0.087 & 0.076 & - & 0.057 & 0.047 \\
\hline IND. EFFECT BY GY & -0.171 & 0.025 & -0.193 & -0.179 & 0.100 & 0.355 & - & -0.027 \\
\hline IND. EFFECT BY GI & 0.078 & 0.012 & 0.122 & -0.079 & 0.188 & 0.109 & -0.010 & - \\
\hline TOTAL & -0.104 & 0.010 & -0.102 & -0.271 & 0.242 & 0.516 & 0.897 & 0.257 \\
\hline Determination coefficient & 0.880 & & & & & & & \\
\hline $\mathrm{K}$ value & 0.018 & & & & & & & \\
\hline Residual effect & 0.140 & & & & & & & \\
\hline Matrix determinant & 0.014 & & & & & & & \\
\hline
\end{tabular}


The traits days to flowering (DF), reproductive period (RP) and cycle duration (CD), revealed null direct effects on the oat milling yield. For the indirect effects of DF, a low and negative effect was observed through GY. Regarding CD, a low and positive indirect effect was expressed through GI on MY. On the other hand, allow and negative effect through GY. Oat genotypes with a short vegetative period tended to have their cycle reduced, but did not reveal changes in the reproductive period, resulting in early and high yielding, but reduced the higher than two-millimeter grain index. Oat is characterized by having a compensatory effect on its cycle duration, showing plasticity to modify the duration of the vegetative or reproductive period, but keeping the total cycle unchanged (Hartwig et al., 2006). The total correlation between the traits CD and DF have proved to be low and negative $(r=-$ $0.10)$ and $(r=-0.10)$ respectively, this association proved by means of indirect effects of the explanatory traits on the industrial yield of oats.

The lodging percentage (LP) revealed null direct effects on the milling yield of oat. This trait has become dependent to the genetic constitution of the genotype used, environmental factors and management techniques, mainly nitrogen availability (Lângaro et al. 2014). Null direct effects between explanatory trait and dependent does not mean lack of relation, but low linearity of response (Cruz et al. 2012). Low and negative indirect effects were observed with the GY, and total correlation was low and negative $(r=-0.27)$. The influence of lodging on the grain yield is mainly through the decrease of plant numbers, panicles and grains in permanent contact with the ground losses quality and health, reducing the industrial potential of oat (Hartwig et al. 2007). Studies revealed that some cultural practices can minimize the plant lodging, and consequently increase grain yield (Hawerroth et al. 2015).

The Thousand grain weight (TGW) presented null direct effects on the milling yield. Low and positive indirect effects were evidenced with the GY and the Gl. The total correlation ( $r=0.24)$ was low and positive, due to the effect of the explanatory traits. The phenotypic interrelationships show that the oat milling yield is not only dependent on grain mass, but also on the amount of grain produced per unit area, and that these are higher and uniform. Studies show that the increase in grain mass implies the decrease in the number of grains per area, with an antagonistic relationship between these (Luche et al. 2013).

The hectoliter weight (HW) showed positive direct effects on the milling yield of oat. Intermediate and low, but positive indirect effects were observed through GY and Gl, respectively. The cause and effect actions indicated that the hectoliter weight has a direct influence on milling yield, in this way can be considered as crucial for the use of indirect selection to obtained superior genotypes in a breeding program, as well as reveal high relation causal, it provides quick and easy calibration and can be used with an effective tool for the breeder. The HW may indirectly indicate the quality of the grains produced, these being well formed and larger with higher utilization by industry (Lângaro et al. 2014).

The grain yield showed high and positive direct effect on milling yield, and total correlation was high and positive $(r=0.90)$. The results obtained for this association showed that the productive potential of oat was mainly to improve industrial efficiency, so the indirect selection can be effective through the GY trait aiming to obtain a highly profitable genotype in industry.

The grain index (GI) showed intermediate and positive direct effect on the dependent trait, and the total correlation revealed a low and positive $(r=0.26)$, which shows the association between these traits. Thus, the grain index presents itself as an alternative to select superior genotypes as regards to the milling yield, but the genotype should have uniform grain filling, grains with higher dimensions and with more weight to obtain high levels of grains larger than two millimeters (Alves and Kist 2010).

The results of this study showed that higher grain yield, hectoliter weight and grain index when reconciled in an oat genotype, result in the increase of the industrial quality potential in similar proportions. However, the simultaneous selection of these traits is not an easy task due to the strong influence of the environment on them (Doehlert et al. 2001).

The phenotypic associations exposed in this study were effective to guide the choice of which traits should be used to compose the indirect selection strategy, and get oat genotypes with higher milling yield. Therefore, the interrelations obtained are reliable because they represent a large sample size $(\mathrm{N}=240)$, and a high determination coefficient $\left(R^{2}=0.88\right)$, with low residual effect $(0.14)$. In this way, the breeder to target more effective in the selection strategy can consider the hectoliter weight, grain yield, and grain index to obtain genotypes with high milling yield.

In conclusion, different phenotypic classes were obtained for the traits measured in the oat genotypes; the milling yield is directly associated with the hectoliter weight, grain yield and grain index; and the phenotypic associations can be effectively used in oat breeding programs aimed at indirect selection to improve milling yield. 


\section{Acknowledgments}

The autors thank National Council for Scientific and Technological Development (CNPq), the Higher Education Personnel Improvement Coordination (CAPES) and the Support Foundation of the Rio Grande do Sul State Research (FAPERGS), for grants and scholarships.

\section{References}

Alves AC and Kist V. 2010. Composição da espigueta de aveia branca (Avena sativa L.). R. Bras. Agrociência 16:29-33.

Barbosa Neto JF et al. 2000. Progresso genético no melhoramento da aveia-branca no sul do Brasil. Pesquisa Agropecuária Brasileira 35:1605-1612.

Caierão E et al. 2001. Seleção indireta em aveia para o incremento no rendimento de grãos. Ciência Rural 31:231-236.

Carvalho FIF de et al. 2004. Estimativas e implicações da correlação no melhoramento vegetal Pelotas: UFPel.

Castro GSA et al. 2012. Ecofisiologia da aveia branca. Scientia Agrararia Paranaensis. 11:1-15.

Crestani $\mathrm{M}$ et al. 2010. Conteúdo de $\beta$-glucana em cultivares de aveia-branca cultivadas em diferentes ambientes. Pesquisa Agropecuária Brasileira 45:261-268.

Cruz CD et al. 2012. Modelos biométricos aplicados ao melhoramento genético. Viçosa: UFV.

Cruz CD 2013. GENES - a software package for analysis in experimental statistics and quantitative genetics. Acta Scientiarum. Agronomy 35:271-276.

Cruz CD et al. 2014. Modelos biométricos aplicados ao melhoramento genético. Viçosa: UFV.

Doehlert DC et al. 2001. Genotypic and Environmental Effects on Grain Yield and Quality of Oat Grown in North Dakota. Crop Science 41:10661072.

Duarte V de F et al. 2017. Caracterização do filocrono e da transição meristemática em aveia hexaplóide In: Lângaro NC et al. (Eds). XXXVII

Reunião da Comissão Brasileira de Pesquisa de Aveia: resultados experimentais. Passo Fundo: UPF. pp.72-77.

Dumlupinar Z et al. 2012. Correlation and Path Analysis of Grain Yield and Yield Components of Some Turkish Oat Genotypes. Pakistan Journal of Botany 44:321-325.

Federizzi LC et al. 2014. Importância da cultura da aveia. In: Lângaro NC and Carvalho IQ de (Eds). Indicações técnicas para a cultura da aveia. Passo Fundo: UPF. pp.13-23.

Hartwig I et al. 2006. Correlações fenotípicas entre caracteres agronômicos de interesse em cruzamentos dialélicos de aveia branca. Revista Brasileira de Agrociência 12:273-278.

Hartwig I et al. 2007. Variabilidade fenotípica de caracteres adaptativos da aveia branca (Avena sativa L.) em cruzamentos dialélicos. Ciência Rural 37: 337-345.

Hawerroth MC et al. 2014. Importância e dinâmica de caracteres na aveia produtora de grãos. Brasília: Embrapa.

Hawerroth MC et al. 2015. Redução do acamamento em aveia-branca com uso do regulador de crescimento etil-trinexapac. Pesquisa Agropecuária Brasileira 50:115-125.

lannucci A et al. 2011. Evaluation of genotype diversity in oat germplasm and definition of ideotypes adapted to the Mediterranean environment. International Journal of Agronomy 2011:1-8.

Jamil M et al. A Review on multidimensional aspects of oat (Avena sativa) crop and its nutritional, medicinal and daily life importance. World Applied Science Journal 34:1269-1275.

Lângaro NC et al. 2014. Cultivares de aveia, qualidade de sementes e implantação da cultura In: Lângaro NC and Carvalho IQ (Eds). Indicações técnicas para a cultura da cultura da aveia. Passo Fundo: UPF. pp. 44-53.

Lorencetti $C$ et al. 2005. Capacidade combinatória e heterose em cruzamento dialélico de aveia (Avena sativa L.). Revista Brasileira de Agrociência 11:143-148.

Luche HS et al. 2013. Desempenho per se e parâmetros genéticos de linhagens de trigo com expressão do caráter "stay-green." Pesquisa Agropecuária Brasileira 48:167-173.

Luche HS et al. 2014. Desenvolvimento da planta In: Lângaro NC and Carvalho IQ de (Eds). Indicações técnicas para a cultura da aveia. Passo Fundo: UPF. pp. 54-62.

Nornberg R et al. 2014. Adaptabilidade e estabilidade de genótipos de aveia branca. Revista Acadêmica: Ciência Animal 12:181-190.

Oliveira AC et al. 2011. Brisasul: a new high-yielding white oat cultivar with reduced lodging. Crop Breeding and Applied Biotechnology 11:370374.

Wright S. 1921. Correlation and causation. Journal of Agricultural Research 20:557-585. 